\title{
Regaining Loyalty in Wealth Management: An Empirical Behavioural Inquiry in the Geneva Private Banking Sector
}

\author{
Philip Edward Chowney and Emmanuel Fragnière
}

\begin{abstract}
The Geneva Private Banking sector has suffered two major shocks in the past five years. The financial crisis and the end of the Swiss banking secrecy have presented this highly sensitive area of service with a new challenge: how to regain their disillusioned customer's faith. The time has come to reconsider what the client needs in terms of service in order to re-establish long term loyalty between banks and their clients. Using ethnomethodology as our research tool, we have been able to study behavioural issues involved in this relationship, as opposed to articulated and codified professional standards. Having interviewed sixty people, half of which are wealth managers, half of which are clients, we were able to make tangible the essence of this tacit knowledge leading to loyalty in private banking. The results of our research draw us to believe that service delivery primes over that of financial gain in terms of performance perceived by the client. The ultimate aim of our research is to provide insights into how behavioural aspects of the wealth management experience may be improved.
\end{abstract}

Index Terms-Wealth management, loyalty behaviour, financial crisis, banking secrecy, tacit knowledge.

\section{INTRODUCTION}

The trusted relationship, at the core of wealth management, has been damaged. Clients not only feel disillusioned by the financial markets, affected by a financial crisis that has resulted in high volatility and great uncertainty in the future prospects of investments, but the end of Swiss banking secrecy has meant they also feel betrayed by their banks. Secrecy no longer being their Unique Selling Point, Swiss banks are now on an equal footing with other providers of professional wealth management services (e.g. New York and London) and will therefore have to compete on the basis of quality of service.

The quality of service in the private banking sector can be separated into two main components: on one hand we have the logistical aspects of the banking services, such as portfolio allocation, back office operations and compliance risk regulations, all of which involve mostly explicit knowledge, meaning that it can be articulated, codified and readily transmitted to others. On the other we have the social aspect of the service experience, comprising essentially of tacit knowledge, based on experience, know-how that cannot be easily codified[1], [2].

Through an ethnomethodological approach to this

Manuscript received August 11, 2013; revised October 14, 2013

Philip Chowney is with the Haute Ecole de Gestion de Genève, 1227 Carouge, Switzerland (e-mail: pchowney@ bluewin.ch).

Emmanuel Fragnière is with the University of Bath, England and the Haute Ecole de de Gestion de Genève, Switzerland (e-mail: manu.fragniere@gmail.com). situation we offer a renewed understanding of the notion of quality of service in the private banking sector. Having interviewed sixty people, half of which are wealth managers, half of which are clients, we were able to pin down the essence of loyalty in private banking (please refer to Table I for further information). With the desire to reassess the client's needs in terms of service in order to re-establish long term loyalty between banks and their clients [3], [4], the ultimate aim of this research is to provide insights into how behavioural aspects of the wealth management experience may be improved [5] (please refer to Table III for a summary of the key findings).

This study is structured around a brief introduction to service science, followed by an explanation of the chosen research design, presenting the ethnomethodological approach used to investigate the missing link to a loyal relationship in private banking. This section is pursued by a synthesis giving a detailed analysis of what is most important to the client and the banks, ending with a discussion and conclusion section summarising the results of our fieldwork. Throughout our research, we define loyalty as having continuing allegiance for one's bank.

\section{SERVICE SCIENCE}

Service science is an emerging academic field that attempts to better address the particularities of service production. This section presents some important findings that will help the reader to understand the important role that ethnomethodology plays in service science [6]. The raw material of service production is known to be knowledge. In service science, we make the distinction between explicit and tacit knowledge. Whereas explicit knowledge can be articulated, codified and readily transmitted to others, tacit knowledge, based essentially on know-how and experience, cannot.

In working toward a notion of "service management" that takes a holistic view of the client's overall satisfaction with the delivery of a service and seeks to adjust all organisational functions to the pursuit of this goal [7] illuminates the need for service science as a way to fully understand the nature and value of coproduction. In today's growing service economy, it is essential for service providers in both the private and public sectors to understand the important roles that creativity, empathy and implicit knowledge play in service coproduction in order to meet the demand for highly customised, expertise-dependent service experiences [8]. These factors are even more linked to the business basis for strong service design when considering the notion that there is a strong relationship between customer satisfaction and "willingness to pay" [9]. 


\section{WHY ETHNOMETHODOLOGY}

Through studying the phenomena that consolidates loyalty in a relationship between a client and their financial institution, in a specific context, with a selected public, ethnomethodology has enabled us to focus on the tacit knowledge involved in guaranteeing loyalty.

In his article "Ethnomethodology's program", Harold Garfinkel [10] defines ethnomethodology as follows:

"Ethnomethodology's fundamental phenomenon and its standing technical preoccupation in its studies is to find, collect, specify, and make instructably observable the local endogenous production and natural accountability of immortal familiar society's most ordinary organisational things in the world, and to provide for them both and simultaneously, as objects, and procedurally, as alternate methods".

Because most services rely on human factors such as expertise, implicit knowledge, empathy, and other immeasurable qualities, most quantitative modelling techniques are insufficient for studying and evaluating the current state of a service environment. Ethnomethodology provides a useful tool for studying the contexts, behaviours, and activities that compose a given service environment, and for gathering the information and insights necessary for suggesting iterative improvements.

\section{RESEARCH DESIGN}

With a desire to reassess the client needs in terms of service in order to re-establish long term loyalty between banks and their clients, we designed a questionnaire using ethnomethodology as our research tool (please see Table II for full questionnaire). This allowed us to study the tacit knowledge involved in this specific relationship.

In [11] the authors state: "its purpose is to describe and explain the social world that the research subjects inhabit in the way in which they would describe and explain it. It is a very appropriate strategy in business, if the researcher wishes to gain insights about a particular context and better understand and interpret it from the perspectives of those involved". This approach is well suited for understanding the underlying constituents of loyalty in a specific area such as private banking.

\section{Questionnaire and Interviews}

Sixty semi-directed (face-to-face) interviews were conducted between 2009 and 2011. Careful consideration was given in selecting the interviewees. Half were wealth managers, the other half were wealth management clients.

The semi-structured interviews [12] were designed to provide respondents with enough freedom to discuss and share their experiences with the analyst, who would then either redirect the interview to explore additional patterns, or conduct further interviews [13]. The structure was as follows. The analyst first met the respondents, and asked for a few details such as their age, professional situation and fortune (in the case of clients). Each respondent was then asked four questions. Thirty clients were asked, amongst others, the following questions: What are the elements that allow you to feel comfortable with your wealth manager? This question was designed to identify the key elements that actually allow for the client to feel comfortable with their wealth manager. Another question was: What accounts for you staying with your Wealth manager? This questions purpose was to identify, beyond the actual initiation of the relationship, what the wealth manager would have to closely monitor in order to maintain a loyal relationship.

TABLE I: SUMMARY OF RESEARCH DESIGN

\begin{tabular}{lll}
\hline & \multicolumn{1}{c}{ Clients } & Wealth managers \\
\hline $\begin{array}{l}\text { Profile of } \\
\text { interviewee }\end{array}$ & $\begin{array}{l}\text { Minimum wealth of 3 } \\
\text { million Swiss francs }(2 \\
\text { million } £ \text { ) }\end{array}$ & $\begin{array}{l}\text { Dealing with clients } \\
\text { having wealth over 3 } \\
\text { million Swiss francs }\end{array}$ \\
\hline $\begin{array}{l}\text { Number of } \\
\text { interviews }\end{array}$ & 30 & 30 \\
\hline \hline
\end{tabular}

TABLE II: THE QUESTIONS ASKED DURING SEMI-DIRECTED INTERVIEWS

\begin{tabular}{l|l}
\multicolumn{1}{c}{ Questions addressed to clients } & $\begin{array}{c}\text { Questions addressed to wealth } \\
\text { managers }\end{array}$ \\
\hline $\begin{array}{l}\text { Could you describe briefly and in } \\
\text { chronological order a typical } \\
\text { session with your wealth } \\
\text { manager? }\end{array}$ & $\begin{array}{l}\text { Could you describe briefly and in } \\
\text { chronological order a typical session } \\
\text { with your clients? }\end{array}$ \\
\hline $\begin{array}{l}\text { What are the elements that allow } \\
\text { you to feel comfortable with your } \\
\text { wealth manager? }\end{array}$ & $\begin{array}{l}\text { What training have you undertaken } \\
\text { to work as a wealth manager? }\end{array}$ \\
\hline $\begin{array}{l}\text { How and why did you choose } \\
\text { your wealth manager? }\end{array}$ & $\begin{array}{l}\text { What are the criteria for a well } \\
\text { conducted meeting with your } \\
\text { clients? }\end{array}$ \\
\hline with your Wealth manager?
\end{tabular}

The remaining thirty respondents, all wealth managers, were asked, amongst others, the following question: Are you more of a craftsman or a link in the banking chain? This question was asked to seek out just how industrialized or not wealth management is. We wanted to observe the flexibility a wealth manager has as to how they will conduct their service in relation to, on one hand their bank, and on the other, their client.

In terms of population, our empirical research focused on the perceptions among the Geneva financial region and their clients. Geneva, being ranked as Europe's $4^{\text {th }}$ most important financial centre for competiveness by the Global Financial Centre's Index (March 2012), represents a significant financial center in Europe and worldwide.

Our research was conducted from April 2009 to December 2011 by the LEM, the market research laboratory (Laboratoire d'Etudes de marché) of HEG (The Haute Ecole 
de Gestion of Geneva) and the students in their final year of their Master's degree in Luxury Management studying at the HEG (years 2009 to 2011). The data collection consisted of sixty semi-directed interviews, with transcripts by the authors and our post graduate Luxury Management students. HEG created the LEM seven years ago, with the goal of teaching students about social data collection and analysis (e.g., survey research, ethnomethodology and social experimentation). We tend to choose topics of public interest for the Geneva population, where the economy is composed primarily of tertiary sector employers. Among the mandates already carried out by the LEM, let us quote "Consumer Choices Among Alternative Electricity Programs in Geneva - An Empirical Analysis" [14].

\section{RESUlts}

To simplify the analysis, we have used a selection of questions from the interview as the main outline of our research that we have illustrated with actual respondent quotes. In the discussion and conclusion section we will then discuss our proposition related to the main research question.

\section{A. A Typical Meeting between a Wealth Manager and His or Her Client}

The survey results show that during the casual conversation that takes place shortly after the wealth manager and the client meet, generally covering topics such as family, health, personal interests and business, it is crucial that the wealth manager evaluate what his or her client's needs are whilst also installing a climate of trust. This assessment must evolve throughout the meetings to meet the client's ever evolving needs. Senior wealth manager: "the customer profile changes over time. If the client presents a certain profile at age forty-five, this profile will not be the same when he or she retires aged sixty-five. Expectations and appetite for risk will evolve over the years". The survey results also show, almost unanimously, that for the wealth manager the first meeting with a new client is the most important. It will determine whether the client will entrust his money with them and whether they will bond. Senior Wealth manager: "The social aspect of the relationship is very important, wealth managers can't afford to be financial product selling machines". Beyond the performance of the portfolio, what stands out in a significant manner here is the "feeling" a client will get for their wealth manager. This feeling is based on a sense of trust and common understanding.

\section{B. Important Elements Allowing for the Client to Feel at Ease}

The elements allowing for a client to feel at ease are many. For the client to feel comfortable, the essential component is, again, trust. The survey contains recurrent answers such as the respect of the clients' privacy, always dealing with the same person rather than a replacement colleague, good portfolio performance, accessibility of the manger, professionalism of manager and the advantage of the manager being a friend of the family. These elements all contribute positively to the client feeling at ease, and therefore trusting their wealth manager. The elements that stood out though, through the emphasis put on them by the respondents were: the depth of communication with the wealth manager and their sincerity. The language used by the manager must be understandable, that is to say commensurate to the size of the client's portfolio as well as the ability and will to understand. The client does not generally appreciate an incomprehensible or condescending language, potentially leading to a lack of trust. If the manager makes proposals that are not in line with the expectations of the client, the trusted relationship will be lost. To feel at ease, the client must feel that the manager is there to provide information that will enable them to make optimal decisions in terms of their financial strategy. Client, Entrepreneur, 65 years old: When I meet with my wealth manager, he presents me with a report on my current financial situation. He speaks in manner really adapting to my own logic; to my personal way of understanding, because it is important for me to understand the situation. This person knows me very well and is able to reassure me on the preservation of the level of quality of life for my family and myself". The form of communication depends on the client's profile and his or her expectations. Wealth manager: "with customers from the entrepreneurial, liberal segments, my objective is to challenge them, they love it. However for some of the private clients segment, we tend to act more as slaves because they need to be pampered".

In conclusion, the most important elements that came from this question are the language of the wealth manager and his or her sincerity. Having established what allows a client to feel at ease, we then looked at what would insure a client's loyalty to their wealth manager.

\section{Components Underwriting a Client's Loyalty to His or Her Wealth Manager in the Long Term}

Three main constituents of loyalty emerged here from our survey: rapport, performance and the bank.

In terms of rapport, time plays the most important role here. Established trust is difficult to replace because it is built over several years. Rapport and trust are the key elements that maintain a longstanding relationship between the client and his or her wealth manager. It's like with a doctor; you no longer need to repeatedly explain things and the client benefits from the fact that the person in front of them knows them well. Client, 40 years old, entrepreneur: "I have no wish whatsoever to start all over again with someone else and have to tell them all about my life". Client, 36 years old, marketing director: "There is a real quality of service because of our longstanding relationship. I'm not treated like just another customer". These clients, benefiting from long-term relationships with their wealth managers, will tend to stay loyal to their banker, rather than their bank. Client: "I'm bound to my wealth manager. If he changes banks, I'll follow him"

For a relatively smaller portion of respondents, although trust and friendship are established, their main priority is the financial performance of the portfolio. This client profile is willing to change banks or banker immediately if unsatisfied at this level. So this client remains as long as he or she is satisfied with level of portfolio performance. Client: "I tend to not stay long with any wealth manager, or more precisely with a well-defined investment strategy, therefore I am not 
dependent on a particular wealth manager and can change when need be". Client: "Even if I have a good friendship with my wealth manager, if a different bank satisfies me more, I'll leave my wealth manager whilst remaining good friends".

For a minority of interviewees, the bank is primordial and has the greatest influence on the long-lasting relationship. These clients give consideration to the reputation of the bank. Even so, this relationship changes naturally in time in favor of the wealth manager, due to their tacit knowledge being highly valued by the client. Wealth Manager: "I would say that initially there is an 80\%-20\% in favor of the bank for these clients, and that as time passes and the relationship develops, the ratio evens-out".

As a general rule, the higher the loyalty between a wealth manager and his or her bank is, the lower the loyalty between this wealth manager and their clientele, and the lower the loyalty between the bank and the wealth manager, the higher the loyalty between the wealth manager and the clients.

\section{Whether the Wealth Manager Considers Him or Herself More a Craftsman or a Link in a Banking Production Line}

This question allows us to assess the actual capacity of individual wealth managers inside the private banking industry to actually change things. A craftsman would feel relatively more independent than someone considering themselves to be more of a link in a banking "production line", simply executing orders from their hierarchy and following protocol. The answers depended on the financial institution the wealth manager worked for, their years of experience and the amount of money they were dealing with. Generally, the more years of experience a wealth manager gains, the more one becomes independent. Wealth manager: "It goes without saying that the environment in which everyone works is going to affect their way of handling things. I mean, if one is in a family business, managers tend to behave more like a friend than a manager, the reverse is also true because in the bigger, more "industrial banks", the managers all have a similar mode of conduct which somehow prevents them from fully opening to their customers". Wealth manager: "We must not forget that we are dealing with people's money, which has a particularly emotional side. Banks offer all more or less the same products; the service will make the difference." managers working in relatively large banks will tend to feel more like a link in an industrial chain because of the importance of the infrastructure behind them.

\section{DISCUSSION AND CONCLUSION}

Based on our initial statement that the time has come to reconsider what the client needs in terms of service in order to re-establish long term loyalty between banks and their clients; ethnomethodology has allowed us to examine the tacit aspect of this relationship and present the following proposition: In terms of performance perceived by the client, the wealth managers' service delivery primes over that of financial gain.

This means that, in terms of being loyal to one's bank, a majority of clients favour the relationship they have with their wealth manager over the performance of their financial assets. Which brings us back to our context: Swiss banks have to compete on the basis of quality of service, but it's not the financial aspect, rather the social experience that they need to focus on.

TABLE III: SUMMARIZES THE FINDINGS OF EACH QUESTION

\begin{tabular}{|c|c|}
\hline Questions & Main Findings \\
\hline $\begin{array}{c}\text { A typical meeting between wealth } \\
\text { managers and their clients }\end{array}$ & $\begin{array}{l}\text { - Importance of the first meeting } \\
\text { - Significance of the social aspect } \\
\text { - Sense of trust }\end{array}$ \\
\hline $\begin{array}{c}\text { Important elements allowing for } \\
\text { the client to feel at ease }\end{array}$ & $\begin{array}{l}\text { - Depth of communication with the } \\
\text { wealth manager } \\
\text { - Sincerity of the wealth manager }\end{array}$ \\
\hline $\begin{array}{l}\text { Components underwriting a } \\
\text { client's loyalty to their wealth } \\
\text { manager in the long term }\end{array}$ & $\begin{array}{l}\text { By order of importance: } \\
\text { 1. Relationship } \\
\text { 2. Performance } \\
\text { 3. The Bank (reputation) }\end{array}$ \\
\hline $\begin{array}{c}\text { Whether the wealth manager } \\
\text { considers him or herself more of a } \\
\text { craftsman or a link in a banking } \\
\text { production line }\end{array}$ & $\begin{array}{l}\text { Depends on: } \\
\text { - The financial institution } \\
\text { - Years of experience } \\
\text { - The amount of money }\end{array}$ \\
\hline
\end{tabular}

The following quote by a wealth manager from one of the interview transcripts illustrates this point: "We must not forget that we are dealing with people's money, which has a particularly emotional side. Banks offer all more or less the same products; the service will make the difference. "

Having used an ethnomethodological basis in order to develop this proposition, a further validation, using a quantitative survey is deemed necessary. In the case where this proposition turns out to be verified, there would be an urgent need for wealth management to focus their attention on elements of tacit knowledge that convey trust and loyalty. If the quality of the relationship is to be the real differentiator of the future, then financial institutions need to arm their relationship managers with relevant skills, tools and training so that they can fully meet the needs of their clients. We will finish with the following quote from a senior wealth manager in one of the interviews: "The social aspect of the relationship is very important, wealth managers can't afford to be financial product selling machines".

\section{APPENDIX}

Example of a transcript done by one of our Students:

\section{A. Interview with a Client}

Profile of the interviewee

Age: 38

Gender: Male

Occupation: self-employed 
1) Could you describe briefly and in chronological order a typical session with your wealth manager

Our meetings normally occur at my office. We talk about the economy and we exchange our views on markets, the economy and politics. I usually expect to get my banker's views on various markets and products. Foreign exchange markets, derivatives, stock exchanges, bonds, expectations about interest rates are all discussed. I also expect him to advise me on their products like hedge funds, funds of funds, etc. My banker usually comes up with various alternatives after he gets my views and expectations. If we have differing views on markets, I expect him to explain his views further so that he may convince me about his investment ideas. I also want him to explain the risk profile of the investment alternatives he proposes to me. Usually he presents me with a table showing the past performance of the funds he recommends but I also wish to know the correlation of these products with some benchmark indexes and other products such as S\&P500 index or government bonds. I also wish to know the expected standard deviation of these products from their mean returns and how they will perform under the best and worst-case scenarios.

After going through these alternatives, I want my banker to come up with more alternatives about the products I am interested in such as gold, commodities and real estate indexes. He usually sends me an e-mail after the meeting about such products.

We also go over my current investments and my past performance. We talk about what other investments I could have made in the past and what would my return be if I had made such investments in the past. He usually makes me sign a document showing my current balances.

I also want him to talk about the bank's performance and quarterly balance sheet. I want to make sure the bank is in good shape financially and always solvent. I also inquire about what kind of investments other clients are making and the general mood in the investment community.

\section{2) What are the elements that allow you to feel} comfortable with your wealth manager

When my banker is completely clear with me about all points of our «relations ». If he talks about the downside risks of the investment alternatives he is proposing it makes me feel more comfortable. I don't want him just to boast about the past performance. I always want to hear an objective analysis about the current environment and predictions about the future. I don't usually like to be recommended products that I don't understand. Also, I don't feel very comfortable with very fast growing funds.

\section{3) How and why did you choose your wealth manager}

I found about this banker by means of a trusted friend of mine who also manages funds. Conservative nature, strong financials and confidentiality of this banker made me choose him.

\section{4) What accounts for you staying with your Wealth manager}

His and the banks transparent and clear communication policy. His current performance, risk averse approach, as well as objective analyses are the most important factors for me. Also I want to feel $100 \%$ sure that the bank is financially very sound and will stay so under any scenario. I want to get a good return on my investment but I should always be given adequate information on the downside risks. The worst possible loss I will endure should never be more than I already expect. As long as my banker supplies me with such products, I will stay with him.

\section{B. Interview with a Client}

Profile of the interviewee:

Age: 40

Gender: Female

Occupation: Associate Director - Senior Relationship Manager

1) Could you describe briefly and in chronological order a typical session with your clients

Meetings can take place in a variety of locations and indeed countries. Generally the meetings are at the client's home, office, or at the bank. The time can vary from a long social dinner with the whole family or a short specific business related telephone call. I am on call for my clients 24 hours a day. Many live and travel around the world so it is important that they can always contact me. I also travel for meetings to the location that is convenient for them.

\section{2) What training have you undertaken to work as a wealth manager}

My formal education is standard. I did not complete a university degree. I followed an internal training program in a bank, and continued my studies whilst working. I currently hold post graduate diploma with the UK Chartered Institute of Securities and Investments, the CII advanced Financial Planning Certificate, and the Investment management certificate. I have been in this industry for over 20 years now, so my qualifications are less relevant. The proof of my skill is in the maintenance of my client relationships.

\section{3) What are the criteria for a well conducted meeting with your clients}

Only one! A satisfied client! All meetings must be adapted to the style of the client. Some require much technical detail, others like to have an informal chat. A successful meeting will result in the needs of the client being met and if possible exceeding their expectations. A good relationship is never driven by selling products. Your client should be presented with solutions for his specific needs never sold the latest product. The secret to doing this well is to listen and to learn to understand who your client is and what actually motivates them. It is actually very rarely money. It is usually securing the future in some way.

\section{4) Are you more of a craftsman or a link in the banking} chain

Personally I feel that I can create for my clients. This is only possible because I work for a truly professional organization that understands the needs of the private client. I am not targeted to produce income as my bank believe that doing the right thing over time for your client creates loyalty and a long term relationship is a profitable one ! Many banks just think short term and simply make money from clients. Clients' needs are placed secondary to earning profit for the bank. Choose your Banker and your bank carefully! 


\section{5) Student's synthesis of semi-directed interviews}

Beside professional qualities and experience, a private banker's competence depends on a complex mixture of his personal and communicational skills. An art of building a very special and in a way very personal relation is of vital importance in the private banking sector. A possessor of a fortune chooses a private banker according to high and stable reputation of the former and solid financial figures and capability to absorb financial turbulences of the bank he/she works for.

More than ever changing financial situation, hectic markets and broad selection of banking products require from a banker not only to understand but to feel a client's demand and to predict his wishes. A client wants a banker to attend to his unique financial needs and expects fast and correct performance of his orders. Managing a client's portfolio requires adapting to the style of life and to the way of thinking of each single client. As the relationship develops, the private banker becomes not only a manager of assets but a confidant, of the present and the future. A successful and fruitful collaboration may determine "private banker (bank) client" relationships over generations.

\section{ACKNOWLEDGMENT}

We would like to thank the students of LEM-HEG, who participated in the construction of the survey, the data collection, and the transcription of answers. Without them, this research would not have been possible.

\section{REFERENCES}

[1] L. Cohen, P. P. Maglio, and R. Barret, "The expert browser: how to leverage distributed organizational knowledge," paper presented at the Workshop on Collaborative Information Seeking at CSCW'98, Seattle, WA, 1998.

[2] Y. Makino, K. Furuta, T. Kanno, S. Yoshihara, and T. Mase, "Interactive method for service design using computer simulation," Service Science, vol. 1, no. 2, pp. 121-134, 2009.

[3] M. Dubosson, E. Fragnière, and N. Tuchshmid, "Wealth management manufacturing: delivering more value?" The Journal of Wealth Management, vol. 11, no. 4, pp. 48-59, 2009.

[4] M. Zineldin, "The royalty of loyalty: CRM, quality and retention," Journal of Consumer Marketing, vol. 23, no. 7, pp. 430-437, 2006.

[5] A. R. Zablah, D. N. Bellenger, and W. J. Johnston, "An evaluation of divergent perspectives on customer relationship management: towards a common understanding of an emerging phenomenon," Industrial Marketing Management, vol. 33, no. 4, pp. 475-489, 2004.

[6] E. Fragnière, F. Moresino, J. Tuberosa, and N. Turin, L'étude de marché en pratique: méthodes et applications, Brussel: Editions de Boeck, 2014.

[7] C. Grönroos, "From scientific management to service management: A management perspective for the age of service competition," Internat. J. Service Indust. Management, vol. 5, no. 1, pp. 5-20, 1993

[8] J. Spohrer, P. P. Maglio, J. Bailey, and D. Gruhl, "Steps toward a Science of Service Systems," Computer, vol. 40, pp. 71-77, 2008.

[9] C. Homburg, N. Koschate, and W. D. Hoyer, "Do satisfied customers really pay more? A study of the relationship between customer satisfaction and willingness to pay," J. Marketing, vol. 69, no. 2, pp. 84-96, 2005.

[10] H. Garfinkel, "Ethnomethodology's program," Soc. Psych. Quart., vol. 59, no. 1, pp. 5-21, 1996.

[11] M. Saunders, P. Lewis, and A. Thornhill, Research Methods for Business Students, 4th edition, NJ: Harlow Pearson Education, 2007.

[12] J. C. Combessie, La Méthode En Sociologie, Paris: La Découverte, 1999.

[13] M. L. G. Perret, D. Gotteland, C. Haon, and A. Jolibert, Méthodologie de la recherche: réussir son mémoire ou sa thèse en sciences de gestion, Paris: Pearson Education France, 2009.

[14] S. Weber, A. Baranzini, and E. Fragniere, "Consumers' choices among alternative electricity programmes in Geneva - an empirical analysis," Int. J. of Global Energy Issues, vol. 31, no. 3-4, pp. 295.309, 2009.

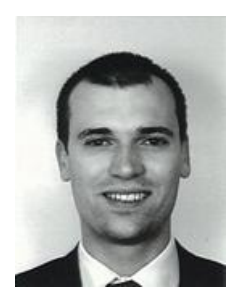

Philip Edward Chowney has a master's degree in Management \& Service Engineering from the University of Applied Sciences of Western Switzerland (2010). He administered the Market Research Laboratory (LEM) of the Haute Ecolde de Gestion of Geneva (HEG) from 2008 to 2011 and was a teacher there in Supply Chain Management in 2012. $\mathrm{He}$ is currently doing research in Service Management at the HEG where he specializes in social-empirical studies and collaborates with public and private companies as an external consultant on a regular basis.

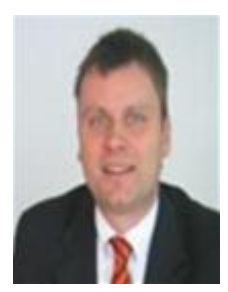

Emmanuel Fragnière is from the CIA (Certified Internal Auditor), he is a professor of service science at the Haute École de Gestion de Genève, Switzerland. $\mathrm{He}$ is also a lecturer in enterprise risk management at the Management School of the University of Bath. His research is focused on the development of risk management models for decision makers in the service sector. He has published several papers in academic journals such as Environmental Modelling and Assessment, Interfaces, Management Science and Service Science. 